\section{Composite materials based on zeolite-montmorillonite rocks and aluminosilicate wastes}

Olga B. KOTOVA - Institute of Geology, Komi Science Center, Ural Branch of the Russian Academy of Sciences, Russian Federation • kotova@geo.komisc.ru

DMıTRY A. SHUSHKOV - Institute of Geology, Komi Science Center, Ural Branch of the Russian Academy of Sciences, Russian Federation - dashushkov@geo.komisc.ru

LÁszLó A. GÖMZE - Institute of Ceramics and Polymer Engineering, University of Miskolc, Hungary - femgomze@uni-miskolc.hu

EMESE KUROVICS - Institute of Ceramics and Polymer Engineering, University of Miskolc, Hungary - fememese@uni-miskolc.hu

GRIGoRIY V. IGNATIEV - Institute of Geology, Komi Science Center, Ural Branch of the Russian Academy of Sciences, Russian Federation • ignatiev.grigoriy@gmail.com

Petr A. SITNIKOV - Institute of Chemistry, Komi Science Center, Ural Branch of the Russian Academy of Sciences, Russian Federation = sitnikov-pa@mail.ru

YURI I. RYABKOV - Institute of Chemistry, Komi Science Center, Ural Branch of the Russian Academy of Sciences, Russian Federation • ryab2012@gmail.com

IRINA N. VASENEVA - Institute of Chemistry, Komi Science Center, Ural Branch of the Russian Academy of Sciences, Russian Federation • ir_vaseneva@mail.ru

Érkezett: 2019. 06. 26. " Received: 26. 06. 2019. " https://doi.org/10.14382/epitoanyag-jsbcm.2019.22

\section{Abstract}

The application of mineral raw materials and their wastes to modify composite materials becomes one of the promising areas of science and industry. This work presents conditions to produce composites in various systems: epoxy polymer matrix/rocks (zeolite + montmorillonite); aluminosilicate waste (coal fly ash). The properties of the initial material and the synthesized composites were studied by standard techniques, XRD and SEM. The operational properties of composites were determined: heat resistance, bending strength, tensile strength, linear shrinkage, apparent density, open porosity, water absorption and crush strength. Keywords: composites, zeolite-montmorillonite rocks, coal fly ash, ceramics Kulcsszavak: kompozitok, zeolit-montmorillonit ásványok, pernye, kerámiák
Olga B. KOTOVA

is professor and Head of Laboratory of Technology of Mineral Raw, Institute of Geology, Komi Science Center, Ural Branch of the Russian Academy of Sciences. Author and co-author of 4 patents and more than 150 scientific articles. Vice-president of International Commission on Applied Mineralogy (IMA-ICAM). Member of Russian Mineralogical Society.

Dmitry A. SHUSHKOV Researcher of Laboratory of Technology of Mineral Raw, Institute of Geology, Komi Science Center, Ural Branch of the Russian Academy of Sciences. Author and co-author of 2 patents and more than 40 scientific articles. Russian Mineralogical Society.

László A. GÖMZE is establisher and professor of the Department of Ceramics and Silicate Engineering in the University of Miskolc, Hungary. He is author or co-author of 2 patents, 6 books and more than 300 scientific papers.

Emese KUROVICS

is graduated from the University of Miskolc, Department of Ceramics and Silicate Engineering as a material engineer, where she continues her study as PhD student under supervision of Prof. L. A. Gömze.

Grigoriy V. IGNATIEV Junior researcher of Laboratory of Chemistry of Mineral Raw, Institute of Geology, Komi Science Center, Ural Branch of the Russian Academy of Sciences. He actually continues his studies as PhD student.

Petr A. SITNIKOV head of the Laboratory of Ultradispersed Systems of the Institute of Chemistry, Komi

\section{Introduction}

The growth of industrial production and consumption of functional materials results in reducing mineral resources and forming large volumes of wastes [1-5]. Environmental problems are becoming more pronounced, special solutions are needed. The application of mineral raw materials and recycling of mineral raw wastes is one of the promising trends of modification of composite materials, an integral part of the regional economy, including creation of new technologies for the construction industry, for the regeneration of ecosystems, etc. [6-10]. The main purpose of modification of the epoxy composite material is to reduce costs and improve operational properties. We noted that the physical-technical properties of the composites based on the epoxy binder could be improved by introduction of modifying additives [11]. Natural layered and porous silicates (montmorillonite or zeolite) are used as such additives [12-14].

The specified natural materials are convenient test objects for modeling composites with desired properties. Depending on the amount of impurities, a change in the structure is possible (increasing volume of intracrystalline cavities or "swelling" of lattices) and the formation of a hybrid nanocomposite [14]. For modeling it would be interesting to show the effect on the physical and chemical properties of the composite by
Science Center, Ural Branch of the Russian Academy of Sciences, associate professor His research was published in 1 book, more than 50 scientific articles, 8 patents. The participant of many international conferences and symposia. Member of the Russian Chemical Society named after D.I. Mendeleev.

Yuri I. RYABKOV

head of the Department of "Chemistry and Physics of Materials" of the Institute of Chemistry, Komi Science Center, Ural Branch of the Russian Academy of Sciences, Ph.D. Specialist in the field of materials science of ceramic and ceramic matrix composites based on oxides and carbides. He is the author and co-author of more than 100 articles, 6 monographs, 21 patents. Member of the Russian Chemical Society named after D.I. Mendeleev.

Irina N. VASENEVA

Junior Researcher, Institute of Chemistry, Komi Science Center, Ural Branch of the Russian Academy of Sciences. Specialist in the field of physico-chemical bases of creating composite materials. She is a co-author of more than 20 articles, 11 patents. Member of the Russian Chemical Society named after D.I. Mendeleev.

the organomodifier, which is a mixture of rocks containing montmorillonite and zeolite. Deposits of montmorillonite or zeolite formed over several thousand years. Therefore, they can have very different mineralogical, chemical, morphological and grain size structures, depending on their position and location within the deposits and strata. We presented results of study of the physical and chemical features of the synthesis of the polymer composite material in the epoxy-polymer matrix/ rock system containing zeolite and montmorillonite. 


\begin{tabular}{|c|c|c|c|c|c|c|c|c|c|c|c|c|c|c|}
\hline Component & $\mathrm{SiO}_{2}$ & $\mathrm{TiO}_{2}$ & $\mathrm{Al}_{2} \mathrm{O}_{3}$ & $\mathrm{Fe}_{2} \mathrm{O}_{3}$ & $\mathrm{FeO}$ & Mno & $\mathrm{CaO}$ & MgO & $\mathrm{K}_{2} \mathrm{O}$ & $\mathrm{Na}_{2} \mathrm{O}$ & $\mathbf{P}_{2} \mathbf{O}_{5}$ & $\mathrm{SO}_{3}$ & loi & Total \\
\hline $\begin{array}{l}\text { Analcime-mont- } \\
\text { morillonite rock }\end{array}$ & 56.50 & 0.95 & 19.42 & 7.71 & 0.28 & 0.04 & 0.68 & 1.62 & 1.54 & 1.65 & 0.10 & - & 9.35 & 99.84 \\
\hline Coal fly ash & 61.24 & 1.06 & 16.87 & 12.69 & 2.30 & 0.06 & 1.86 & 2.01 & $\mathrm{~K}_{2} \mathrm{O}$ & $\mathrm{Na}_{2} \mathrm{O}$ & $\mathrm{P}_{2} \mathrm{O}_{5}$ & 0.11 & 0.9 & 99.87 \\
\hline
\end{tabular}

Table 1. The chemical composition in wt. \% of analcime-montmorillonite rock and fly ash

1. táblázat Az analcime-montmorillonit ásvány és a pernye kémiai összetétele

The application of aluminosilicate wastes for composite ceramics is also becoming a modern innovative trend. For example, the possibility of obtaining glass ceramics and ceramics from coal fly ash with the addition of natural raw materials and industrial wastes: quartz, clay, talc, broken glass, dolomite, wastes from the processing of borax and titanium was shown [15-19]. However, there are very few studies in the field of ceramics synthesis with application of only fly ash $[20,21]$. In this paper we showed the possibility of obtaining ceramics from fly ash without addition of other components and revealed conditions for obtaining materials with optimum strength and water absorption properties.

The aim of the work is to obtain new knowledge in the field of formation, stability of phase transformations and aggregation of ultrafine substances and creation of composite materials with desired properties based on natural and technogenic raw materials.

\section{Materials and experiments}

\subsection{Materials}

Montmorillonite - (nanoclay) - clay mineral of the subclass of layered silicates. The crystalline structure of montmorillonite allows using surface active centers and changing the dimensions of interlayer voids and injecting "foreign" molecules into them [13].

Zeolites - aluminosilicates of alkali and alkaline-earth metals - are porous bodies characterized by a specific framework structure and regular pore geometry (intracrystalline cavities and channels) into which foreign molecules can penetrate after dehydration. By variation of the exchangeable cations and the aluminosilicate framework (i.e., type of zeolite), it is possible to regulate the physical and chemical interactions involving sorbed molecules $[22,23]$. In this paper the aluminosilicate minerals of the zeolite class were represented by analcime.

Samples of analcime-montmorillonite rocks, selected from the Veslyana zeolite deposit (Koinskaya zeolite area, Komi Republic, Russia), were used as the mineral component. The mineral composition of the analcime-montmorillonite rocks: montmorillonite - 35, analcime - 25, quartz - 20, feldspars - 10 , kaolinite -5 , calcite $-5 \%$. The chemical composition is presented in Table 1. We described more details of the mineral composition of the analcime-montmorillonite rocks, their physical and chemical properties and their application in $[4,10,24,25]$.

The present study used a commercially available epoxy resin based on diglycidyl ether of bisphenol-A (DGEBA) with the trademark ED-20, and the curing agent was isomethyltetrahydrophthalic anhydride (iso-MTHPA). The chemical structures of the materials are shown in Fig. $1 a, b$.

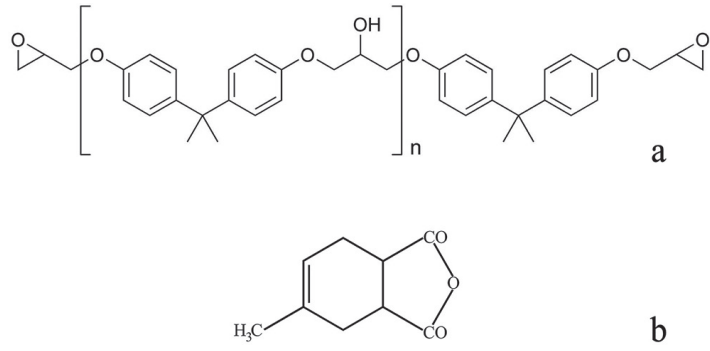

Fig. 1 Chemical structures of diglycidyl ether of bisphenol- $A, n=0.98$ (a) and isomethyltetrahydrophthalic anhydride (b)

1. ábra A biszfenol-A, $n=0,98$ (a) és izo-metil-tetrahidro-ftálsav-anhidrid (b) kémiai szerkezete

Coal fly ash and slag are industrial wastes from the combustion of coal in thermal power plants. To obtain ceramic materials we used the coal fly ash from thermal power plants of Vorkuta town, which use hard coal from the mine "Vorgashorskaya" (Pechora coal basin, Russia). XRD analysis revealed quartz, mullite, magnetite, hematite and amorphous phase (probably silicate or aluminosilicate glass). The chemical composition is shown in Table 1. Detailed information on the composition and structure of the fly ash and methods of its utilization are presented in $[5,26]$.

\subsection{Preparation of composite materials}

The stoichiometric quantities of epoxy resin and anhydride hardener were mixed at a mass ratio of 100 to 80 at a temperature of $75^{\circ} \mathrm{C}$. The components were stirred for 15 minutes at the same temperature to obtain a homogeneous mixture. The product is added analcime-montmorillonite rock in the required ratio. The distribution of dispersed powder was carried out on an ultrasonic generator (Il - 10-0.1) for 20 minutes. Then the mixture was poured into a metal mold with non-stick coating. Degassing was carried out inside the vacuum chamber at 0.1 bar. Preparation of the epoxy composite was carried out by a three-stage curing cycle. First, the mixture was kept at $100{ }^{\circ} \mathrm{C}$ for 1 hour, then at $120^{\circ} \mathrm{C}$ for 1 hour and the polycondensation mode was completed at $160{ }^{\circ} \mathrm{C}$ for 3 hours. Polymer composite sheets were cooled in the desiccator to room temperature.

To obtain ceramic materials from fly ash, the technique described in [27], was used: $150 \mu \mathrm{l}$ of distilled water was added to $1.5 \mathrm{~g}$ of ash (particle size is less than $0.05 \mathrm{~mm}$ ) and mixed thoroughly in a mortar. The resulting mixture was pressed by a hydraulic press under pressure of 7,21 and $35 \mathrm{MPa}$ and 5 min exposition. As a result, cylindrical tablets with a diameter of $10 \mathrm{~mm}$ and a height of 9-13 $\mathrm{mm}$ were obtained. For pressing the tablets under a pressure of $35 \mathrm{MPa}, 5 \%$ polyvinyl alcohol with a volume of $500 \mu \mathrm{l}$ was used instead of water. Before sintering, the pressed samples were dried at $103{ }^{\circ} \mathrm{C}$ for $8 \mathrm{~h}$ to remove moisture. The annealing was carried out in a muffle furnace at temperatures from 800 to $1250{ }^{\circ} \mathrm{C}(800$, $900,1000,1050,1100,1150,1200,1250^{\circ} \mathrm{C}$ ) for 2 hours. 


\begin{tabular}{lcccccc} 
Analcime-montmorillonite rock, \% (mass.) & $\mathbf{0}$ & $\mathbf{0 . 5}$ & $\mathbf{1}$ & $\mathbf{5}$ & $\mathbf{1 0}$ & $\mathbf{1 5}$ \\
\hline Onset temperature, ${ }^{\circ} \mathbf{C}$ & 81 & 60 & 81 & 83 & 85 \\
\hline Max temperature, ${ }^{\circ} \mathbf{C}$ & 123 & 105 & 124 & 127 & 128 & 130 \\
\hline End temperature, ${ }^{\circ} \mathbf{C}$ & 149 & 126 & 140 & 163 & 161 & 160 \\
\hline Energy effect, $\mathbf{~} / \mathbf{g}$ & 222 & 246 & 229 & 218 & 236 \\
\hline
\end{tabular}

Table 2 DSC data for the process of composite obtaining

2. táblázat DSC adatok a kompozit elóállitási folyamatához

\begin{tabular}{lccccccc}
\multicolumn{1}{r}{ Analcime-montmorillonite filler, wt. \% } & $\mathbf{0}$ & $\mathbf{0 . 5}$ & $\mathbf{1}$ & $\mathbf{5}$ & $\mathbf{1 0}$ & $\mathbf{1 5}$ & $\mathbf{2 5}$ \\
Martens heat resistance, ${ }^{\circ} \mathbf{C}$ & $110 \pm 2$ & $132 \pm 2$ & $123 \pm 2$ & $123 \pm 2$ & $118 \pm 2$ & $115 \pm 2$ & $105 \pm 2$ \\
\hline Tensile strength, $\mathrm{MPa}$ & $44 \pm 4$ & $63 \pm 4$ & $55 \pm 4$ & $53 \pm 4$ & $50 \pm 4$ & $45 \pm 4$ & $35 \pm 4$ \\
\hline Bending strength, $\mathrm{MPa}$ & $110 \pm 5$ & $145 \pm 5$ & $125 \pm 5$ & $125 \pm 5$ & $120 \pm 5$ & $110 \pm 5$ & $100 \pm 5$ \\
\hline
\end{tabular}

Table 3 Characteristics of the composite with analcime-montmorillonite filler

3. táblázat A kompozit tulajdonságai analcime-montmorillonit fillerekkel

\subsection{Methods of investigations}

The phase composition was determined by DRON-4M and Shimadzu XRD-6000 diffractometers. The chemical composition was determined by the method of silicate analysis for $12 / 14$ components.

The study of the processes, occurring at the preparation of the composite material, was carried out by the methods of differential scanning calorimetry (DSC) by Schimadzu DSC-60 device and chemical analysis for functional groups. The content of epoxy groups in epoxy oligomer and carboxyl groups in iso-MTHPA was determined by chemical analysis using standard methods [20]. The strength properties were studied by IR 5057-60 tensile testing machine, which stretched the sample with a given constant rate of movement of active clamp and load measurement with an error of no more than $1 \%$ of the measured value.

The apparent density, open porosity and water absorption were determined according to [28]. The microstructural features were examined by TESCAN VEGA 3 LMH scanning electron microscope with Oxford Instruments X-Max energy dispersive attachment. The crush strength was measured using a universal testing machine (model WDW-T100) at a loading rate of $1 \mathrm{~mm} / \mathrm{min}$.

\section{Results and discussion}

\subsection{Epoxy polymer matrix/analcime+montmorillonite rock}

The data obtained by DSC and chemical analysis for functional groups showed no interaction between components of the polymer matrix and the filler particles, i.e. we can say that the improvement of the operational properties of the material is resulted from the physical adsorption caused by hydrogen bonds, forming an additional strong lattice compensating for the growth of heterogeneity and imperfection in the boundary layers.

Fig. 2 shows a characteristic view of DSC curves of the hardening process upon receipt of a composite material. Table 2 shows the onset, maximum and end temperatures of the exothermic peak, as well as observed exothermic effect of the reaction. It is noted that with the increase of the content

of analcime from 1 to $15 \mathrm{wt} . \%$, there is a slight increase of the temperatures of the onset of the reaction during preparation of the composite material. At the same time for ED-20+isoMTHPA+analcime-montmorillonite rock mixture at low concentrations of the filler (about 0.5 wt.\%), oligomer molecules in the adsorption layer are likely to be ordered because of orientation of its polar groups (glycidyl, hydroxyl) with respect to the particles of analcime-montmorillonite containing rock, which creates a "kinetically advantageous" order in it and catalyzes the hardening process, which starts at $20{ }^{\circ} \mathrm{C}$ lower temperature. The thermal-temporal mode of hardening was at: $100^{\circ} \mathrm{C}-2 \mathrm{~h}, 120^{\circ} \mathrm{C}-2 \mathrm{~h}, 160^{\circ} \mathrm{C}-3 \mathrm{~h}$.

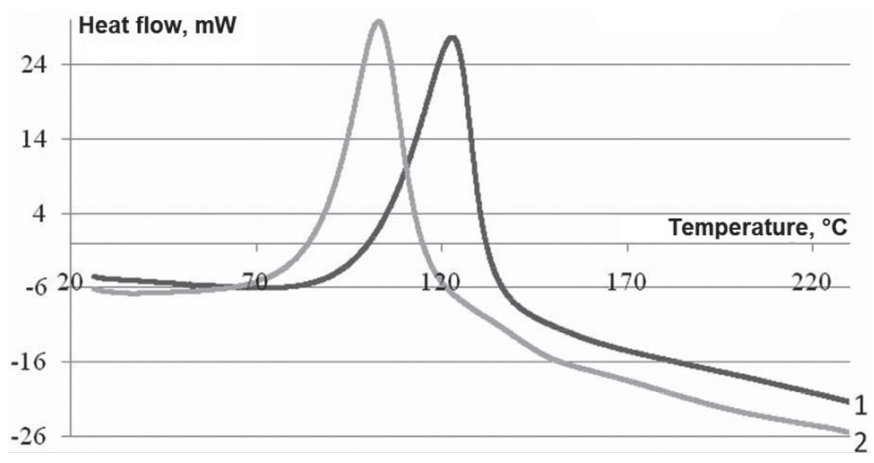

Fig. 2 DSC curves of polymerization process in the systems: 1 - ED-20+iso-MTHPA; 2 - ED-20+iso-MTHPA+0.5 wt.\% analcime-montmorillonite rock

2. ábra A polimerizációs folyamat DSC görbéi: $1-E D-20+i z o-M T H P A$ valamin $2-E D-20+i z o-M T H P A+0,5$ tömeg\% analcime-montmorillonit ásványrendszerekben

The study of the performance characteristics of the composite (Table 3), such as Martens heat resistance, bending strength, tensile strength, showed that for samples with a filling of $0.5 \mathrm{wt} . \%$ had the best results due to the effect of small additives. The improved performance is associated with the formation of reinforcing frame filler particles, the orientation of macromolecules and their transition into thin hardened films, but the main factor is the adhesion of the polymer to solid surfaces. Generally, adhesion in polymers is resulted from physical (including hydrogen) bonds, which form an additional strong lattice, which compensates the growth of heterogeneity and imperfection in the boundary 
layers. However, with increasing interaction of the polymer with the surface of the filler particles, internal stresses also increase and weaken the composition. This interaction changes the structure and properties of the material in the boundary layers, the latter increases proportionally with the growth of the specific interface.

The increase of the content of the filler (from 1 to $10 \mathrm{wt}$ \%) results in the decrease of modifying effect, and filling more than 15 wt. $\%$ affects properties of the polymer matrix.

\subsection{Ceramics on the basis of coal fly ash}

The experiments showed that sintering of samples occurred at $1050^{\circ} \mathrm{C}$ and above. The chemical composition of the sintered samples did not generally differ from the chemical composition of initial coal fly ash. The sintered samples showed a low content of $\mathrm{FeO}$, associated with it oxidation to $\mathrm{Fe}_{2} \mathrm{O}_{3}$ when heated, and sulfur, which had volatilized at burning of the organic part of the ash (unburned carbon).

Fig. 3 showed diffraction patterns of the initial fly ash and ceramic materials obtained at temperatures from 800 to 1200 ${ }^{\circ} \mathrm{C}$. Unlike the original fly ash in the sintered samples, peaks of magnetite, converted to hematite, were not diagnosed. With the increase of burning temperature, the intensity of reflections of quartz decreased, and the intensity of mullite increased. At $1200{ }^{\circ} \mathrm{C}$ cristobalite was formed.

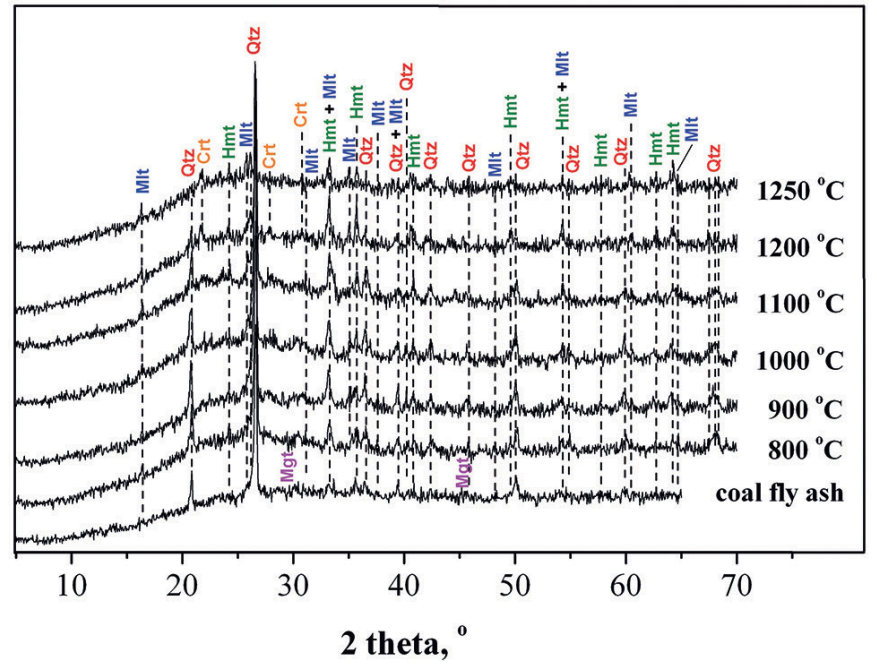

Fig. 3 XRD patterns of fly ash and samples annealed at temperatures of 800-1250 ${ }^{\circ} \mathrm{C}$. Mlt - mullite, Qtz - quartz, Mgt - magnetite, Hmt - hematite, Crt cristobalite

3. ábra $800-1250^{\circ} \mathrm{C}$ hömérsékleten lágyított pernye XRD mintái. Mlt- mullit, Qtzkvarc, Mgt - magnetit, Hmt - hematit, Crt - cristobalite

We determined linear shrinkage, apparent density, open porosity, water absorption and crush strength for the obtained ceramic samples.

Linear shrinkage of the samples pressed at 7 and $21 \mathrm{MPa}$ and annealed at $1100-1150{ }^{\circ} \mathrm{C}$ was $7.6-11.6 \%$. Annealing at $1200{ }^{\circ} \mathrm{C}$ and higher temperature results in increasing in sample diameter by $2.6-4.8 \%$ with formation of internal pores, i.e. porous ceramics is obtained. The behavior of samples obtained at a pressure of $35 \mathrm{MPa}$ is somewhat different: shrinkage is fixed only at $1100{ }^{\circ} \mathrm{C}$; with increasing temperature the sample diameter increases by $8.1 \%$.
The apparent density of the sample pressed at $7 \mathrm{MPa}$ increases from 1.5 to $2.0 \mathrm{~g} / \mathrm{cm}^{3}$ in the temperature range of $1050-1150$ ${ }^{\circ} \mathrm{C}$. With the increase of apparent density, a significant decrease of open porosity and water absorption occurs. Thus, the open porosity is reduced by 20 times (from 38 to $1.9 \%$ ), water absorption - 26 times (from 25 to $0.9 \%$ ). Annealing at 1200 ${ }^{\circ} \mathrm{C}$ and higher temperature contributes to the formation of internal pores and, accordingly, to the decrease of the apparent density up to $1.2 \mathrm{~g} / \mathrm{cm}^{3}$. The open porosity of porous ceramics was $1.1-1.4 \mathrm{~V} \%$, water absorption was $0.8-1.1 \mathrm{wt}$ \%.

Pressing at 21 and $35 \mathrm{MPa}$ allows increasing apparent density of ceramics, reducing open porosity and water absorption at a given firing temperature. Thus, a sample obtained at $35 \mathrm{MPa}$ and a firing temperature $1100{ }^{\circ} \mathrm{C}$ is characterized by a rather high apparent density $\left(2.46 \mathrm{~g} / \mathrm{cm}^{3}\right)$ and low open porosity and water absorption ( 0.4 and $0.2 \mathrm{wt}$ \%, respectively).

Fig. 4 shows SEM images of the surface of ceramics obtained at various temperatures and pressing pressures. The surface of the samples pressed at 7 and $21 \mathrm{MPa}$ and sintered at 1100 ${ }^{\circ} \mathrm{C}$ looks rough and uneven, which indicates relatively poor sintering. As the temperature rises to $1150{ }^{\circ} \mathrm{C}$, the ash particles stick together, forming a smoother and more uniform surface, which leads to the increase in density and strength. In the samples sintered at $1200^{\circ} \mathrm{C}$, large pores with sizes up to 200 and $600 \mathrm{~mm}$ are observed for pressing pressures of 7 and $21 \mathrm{MPa}$, respectively. The formation of pores is resulted from softening of glass phase of the ash simultaneously with formation of gas phase. The sample, pressed at $35 \mathrm{MPa}$ and sintered at $1100{ }^{\circ} \mathrm{C}$, has the densest and flat surface. Pore formation of samples pressed at $35 \mathrm{MPa}$ was detected at a temperature of $1150^{\circ} \mathrm{C}$.
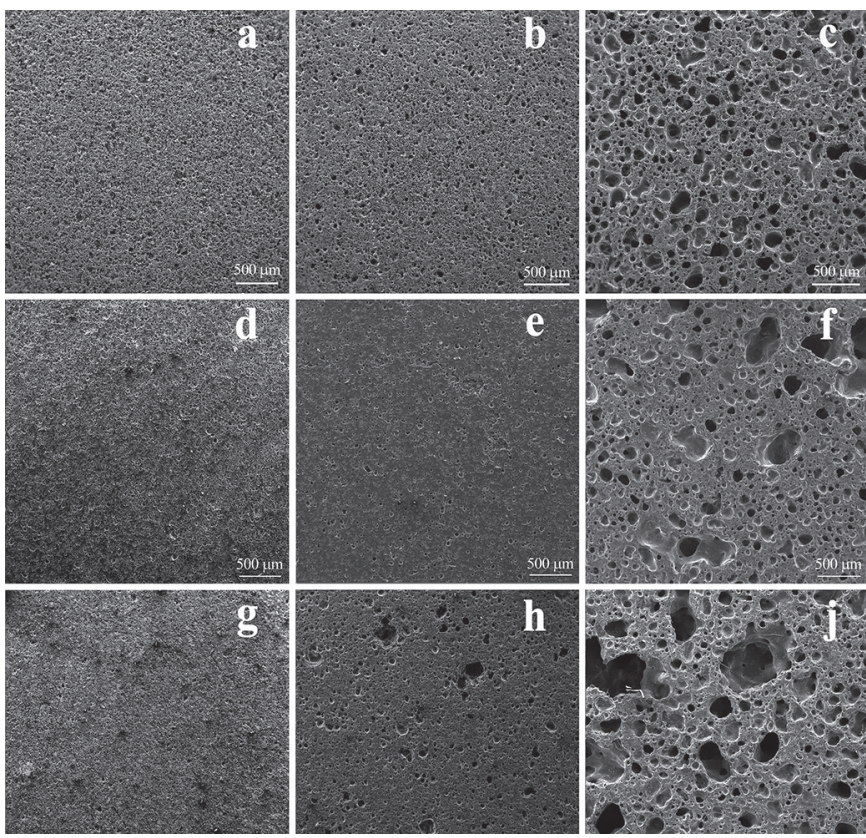

Fig. 4 SEM images of the surface of ceramics obtained at the following values of pressing pressure and firing temperature, respectively: a) $\left.7 \mathrm{MPa}, 1100^{\circ} \mathrm{C}, b\right) 7$ $\left.\mathrm{MPa}, 1150^{\circ} \mathrm{C}, \mathrm{c}\right) 7 \mathrm{MPa}, 1200^{\circ} \mathrm{C}$, d) $\left.21 \mathrm{MPa}, 1100^{\circ} \mathrm{C}, \mathrm{e}\right) 21 \mathrm{MPa}, 1150{ }^{\circ} \mathrm{C}$, e) $\left.\left.21 \mathrm{MPa}, 1200^{\circ} \mathrm{C}, \mathrm{g}\right) 35 \mathrm{MPa}, 1100^{\circ} \mathrm{C}, \mathrm{g}\right) 35 \mathrm{MPa}, 1150^{\circ} \mathrm{C}$, and) $35 \mathrm{MPa}$, $1200{ }^{\circ} \mathrm{C}$

4. ábra A kerámia felületének SEM képei az alábbi sajtoló nyomás és égési hömérsékleteknél: a) $\left.\left.7 \mathrm{MPa}, 1100{ }^{\circ} \mathrm{C}, b\right) 7 \mathrm{MPa}, 1150{ }^{\circ} \mathrm{C}, \mathrm{c}\right) 7 \mathrm{MPa}, 1200^{\circ} \mathrm{C}$, d) $\left.\left.\left.21 \mathrm{MPa}, 1100^{\circ} \mathrm{C}, e\right) 21 \mathrm{MPa}, 1150^{\circ} \mathrm{C}, e\right) 21 \mathrm{MPa}, 1200^{\circ} \mathrm{C}, \mathrm{g}\right) 35 \mathrm{MPa}$, $\left.1100{ }^{\circ} \mathrm{C}, \mathrm{g}\right) 35 \mathrm{MPa}, 1150{ }^{\circ} \mathrm{C}$, and) $35 \mathrm{MPa}, 1200^{\circ} \mathrm{C}$ 
It was established that the annealing temperature significantly affected the crushing strength, unlike the pressing pressure. Thus, the crush strength of samples pressed at 7 and $21 \mathrm{MPa}$ and sintered at $1100^{\circ} \mathrm{C}$ was 63 and $76 \mathrm{MPa}$, respectively. At a firing temperature of $1150{ }^{\circ} \mathrm{C}$, this parameter increased significantly and amounted to 135 and $129 \mathrm{MPa}$, respectively. Increasing the firing temperature to $1200{ }^{\circ} \mathrm{C}$ leads to the formation of large internal pores, as a result of which the crush strength is sharply reduced to 39 and $21 \mathrm{MPa}$.

Thus, we showed that the pressing pressure and the firing temperature affected the characteristics of ceramics: apparent density, water absorption, open porosity, crush strength. According to their technological characteristics, the materials obtained can be used for the production of building ceramics.

\section{Conclusions}

The paper is devoted to composites based on analcimemontmorillonite rocks and aluminosilicate wastes (coal fly ash). We emphasize an important role of integration of mineralogical and technological features of the material composition for predicting behavior in the technological processes of composite formation and their operational characteristics.

The conditions for obtaining a composite polymer material in the epoxy-anhydride matrix/analcime-montmorillonite system have been studied. The optimal conditions $(T, P)$ for the formation of the operational characteristics of composites (heat resistance, bending strength, tensile strength, etc.) are shown.

Improving performance properties of composites is associated with $\mathrm{P}, \mathrm{T}$ conditions, physical adsorption and effect of "small additives".

It is shown that the mechanism of phase transformations in the considered systems (epoxy polymer matrix/ analcime+montmorillonite or aluminosilicate waste (fly ash)) can form new phases, the physical and chemical parameters of which meet the requirements of materials exploitation, expand the list of goods and reduce environmental risks.

\section{Acknowledgments}

The authors express gratitude to the common use center "Geonauka» for their help in analytical work. The work was done on the research theme "Scientific basis for effective subsoil use, development and exploration of mineral resource base, development and implementation of innovative technologies, geological and economic zoning of Timan-Northern Ural region" (ГР No. АААA-A17-117121270037-4) with a partial financial support of UB RAS Programs (project 15-5-5-44)

\section{References}

[1] Ozhogina, E. - Kotova, O. - (2019): New methods of mineral processing and technology for the progress of sustainability in complex ore treatment. 29th International Mineral Processing Congress, Canadian Institute of Mining (IMPC 2018), Metallurgy and Petroleum, 2-s2.0-85059377649

[2] Burtsev, I. N. - Kotova O. B. - Kuzmin D. V. - Mashin, D. O. - Perovsky, I. A. - Ponaryadov, A. V. - Shushkov, D. A. (2018): The role of technological research in the development of the mineral resource complex of the Timan-North Ural region. Razvedka I ohrana nedr (Exploration and protection of mineral resources). No. 5, pp. 38-47. (in Russian)
[3] Kotova, O. B. - Moskalchuk, L. N. - Shushkov, D. A. - Leontyeva, T. G. - Baklay, A. A. (2017): Radionuclide sorbents based on industrial wastes: physical-chemical properties and prospects for use. Vestnik of Institute of Geology of Komi SC of UB of RAS. No. 4, pp. 29-36, http://doi.org/10.19110/2221-1381-2017-4-29-36 (in Russian)

[4] Kotova, O. B. - Harja, M. - Cretescu, I. - Noli, F. - Pelovski, Y. - Shushkov, D. A. (2017): Zeolites in technologies of pollution prevention and remediation of aquation systems. Vestnik of Institute of Geology of Komi SC of UB of RAS. No. 5, pp. 49-53,

http://doi.org/10.19110/2221-1381-2017-5-49-53

[5] Shushkov, D. - Shuktomova, I. - Rachkova, N. - Harja, M. - (2018): Porosity and sorption properties of zeolites synthesized from coal fly ash, Vestnik of Institute of Geology of Komi SC of UB of RAS, No 3, pp. 32-37, http://doi.org/10.19110/2221-1381-2018-3-32-37

[6] Duduman, C. - Cobos, J. - Caso de Los, M. - Harja, M. - Pérez, M. Gómez de Castro, C. - Lutic, D. - Kotova, O. - Cretescu, I. (2018): Preparation and characterisation of nanocomposite material based on TiO2-Ag for environmental applications. Environmental Engineering and Management Journal. Vol. 17 (4), pp. 2813-2821.

[7] Kotova, O. B. - Harja. M. - Kotov, L. N. - Ponaryadov, A. V. (2018): Titanium minerals as prototypes of functional materials with pronounced electromagnetic properties ash. Vestnik of Institute of Geology of Komi SC of UB of RAS. No 4, pp. 34-39,

http://doi.org/10.19110/2221-1381-2018-4-34-39 (in Russian)

[8] Ozhogina, E. G. - Kotova, O. B. - Yakushina, O. A. (2018): Mining wastes: mineralogical features // Vestnik of Institute of Geology of Komi SC of UB of RAS. No. 6, pp. 43-49,

http://doi.org/10.19110/2221-1381-2018-6-43-49 (in Russian)

[9] Schemelinina, T. N. - Kotova, O.B. - Anchugova, E.M. - Shushkov, D. A., Ignatiev, G. V. (2018): Zeolite and clay raw materials: experimental modeling of biogeosorbents. Vestnik of Institute of Geology of Komi SC of UB of RAS. No. 9, pp. 50-57,

http://doi.org/10.19110/2221-1381-2018-9-50-57 (in Russian)

[10] Shushkov, D. A. - Kotova, O. B. - Goldin, B. A. (2011): Geomaterials on the Basis of Analcime-Bearing Rocks. Geomaterials, No 1, pp. 33-40, http://doi.org/10.4236/gm.2011.12006

[11] Erofeeva, A. A. (2006): Epoxy composites with the use of local aggregates, modified with carbamide resins and amidopolyamines. PhD Theses. $20 \mathrm{p}$.

[12] Gerasin, V. A. - Zubova, T. A. - Bahov, F. N. et al. (2007): Structure of polymer $/ \mathrm{Na}^{+}$montmorillonite nanocomposites obtained by melt mixing. Russian Nanotechnologies. Vol. 2, No. 1-2, pp. 90-105. (in Russian)

[13] Schaak, R. E., Mallouk, T. E. (2002): Designer materials: retrosynthesis of new inorganic solids, nano-materials and thin films with controlled structures and morphologies. Chemistry of Materials. Vol. 14, No. 4, pp. 1455-1471, http://doi.org/10.1021/cm010689m

[14] Pomogaelo, A. D. (2006): Synthesis and intercalation chemistry of hybrid organo-inorganic nanocomposites // Vysokomolekulyarnyie Soedineniya (High Molecular Compounds). Ser. S. Vol. 48, No. 7, pp. 1318-1351. (in Russian)

[15] Vilches, L.F. - Fernandez-Pereira, C. - Olivars del Valle, J. - Vale, J. (2003): Recycling potential of coal fly ash and titanium waste as a new fireproof products // Chemical Engineering Journal. Vol. 95, pp. 155-161, http://doi.org/10.1016/S1385-8947(03)00099-8

[16] Artir, R. - Yilmaz, - S. Bindal, C. (2004): Some properties and sintering behavior of $\mathrm{B}_{2} \mathrm{O}_{3}$ added coal fly ash. Key Engineering Materials. Vols. 264268, pp. 2477-2480,

https://doi.org/10.4028/www.scientific.net/KEM.264-268.2477

[17] Chandra, N. - Agnihorti, N. - Bhasin, S. - Khan, A.F. (2005): Effect of addition of talc on the sintering characteristics of fly ash based ceramic tiles. Journal of European ceramic society. Vol. 25, pp. 81-88, http://doi.org/10.1016/j.jeurceramsoc.2004.01.004

[18] Blisset, R. S. - Rowson, N. A. (2012): A review of multi-component utilization of coal fly ash Fuel. No 97, pp. 1-23, https://doi.org/10.1016/j.fuel.2012.03.024

[19] Yao, Z.T. - Ji, X. S. - Sarker, P. K. - Tang, J. H. - Ge, L. Q. - Xia, M. S. - Xi, Y. Q. (2015): A comprehensive review on the application of coal fly ash. 
Earth-Science Reviews. No 141, pp. 105-121, https://doi.org/10.1016/j.earscirev.2014.11.016

[20] Erol, M. - Kucukbayrak, S. - Ersoy-Mericboyu A. (2008a): Comparison of the properties of glass, glass-ceramics and ceramics materials produced from coal fly ash. Journal of Hazardous Materials. Vol. 153, pp. 418-425, http://doi.org/10.1016/j.jhazmat.2007.08.071

[21] Erol, M. - Kucukbayrak, S. - Ersoy-Mericboyu A. (2008b): Characterization of sintered coal fly ashes // Fuel. Vol. 87, pp. 1334-1340, http://doi.org/10.1016/j.fuel.2007.07.002

[22] Treacy, M. M. J. - Foster, M. D. - Randall, K. H. (2006): An efficient method for determining zeolite vertex symbols. Microporous and Mesoporous Materials. Vol. 87, pp. 255-260, http://doi.org/10.1016/j.micromeso.2005.08.024

[23] Sitnikov, P. A. - Vaseneva, I. N. - Belykh, A. G. - Kotova, O. B. - Shushkov, D. A. - Ryabkov, Yu. I. - Kuchin, A. V. (2011): Modelling and working out of technological parameters for obtaining of an epoxy composite material containing analcime-monmorillonite rock. Izvestiya Komi nauchnogo tsentra Uralskogo otdeleniya Rossiyskoy akademii nauk (Proceedings of Komi Science Centre, Ural Branch, Russian Academy of Sciences). No 4 (8), pp. 15-18. (in Russian)

[24] Kotova, O. B. - Shushkov, D. A. (2008): Properties and utilisation of analcime-bearing rocks of the Timan region, Komi Republic, Russian Federation. Australasian Institute of Mining and Metallurgy Publication Series. pp. 515-520.
[25] Shushkov, D. - Kotova, O. - Shuktomova I. (2013): Removal of radionuclides by analcime-bearing rocks. J. Materials Science and Engineering. Vol. 47, pp. 198-202, http://doi.org/10.1088/1757-899X/47/1/012041

[26] Kotova, O. B. - Shabalin, I. N. - Shushkov, D. A. - Kocheva, L. S. (2016) Hydrothermal synthesis of zeolites from coal fly ash. Advances in Applied Ceramics: Structural, Functional and Bioceramics. Vol. 115, Iss. 3, pp. $152-$ 157, http://doi.org/10.1179/1743676115Y.0000000063

[27] Ignatiev, G. V., Shushkov, D. A. (2018): Ceramics on the basis of fly ash from Vorkuta Thermal Power Plant. IX All-Russian Youth Scientific Conference "Minerals: structure, properties, research methods", pp. 77-78. (in Russian)

[28] GOST 2409-95 (Russian State Standard) (1995): Method for determination of bulk density, apparent and true porosity and water absorption. $6 \mathrm{p}$.

\section{$\underline{\text { Ref.: }}$}

Kotova, Olga B. - Shushkov, Dmitry A. - Gömze, László A. Kurovics, Emese - Ignatiev, Grigoriy V. - Sitnikov, Petr A. Ryabkov, Yuri I. - Vaseneva, Irina N.: Composite materials based on zeolite-montmorillonite rocks and aluminosilicate wastes Építőanyag - Journal of Silicate Based and Composite Materials, Vol. 71, No. 4 (2019), 125-130. p. https://doi.org/10.14382/epitoanyag-jsbcm.2019.22

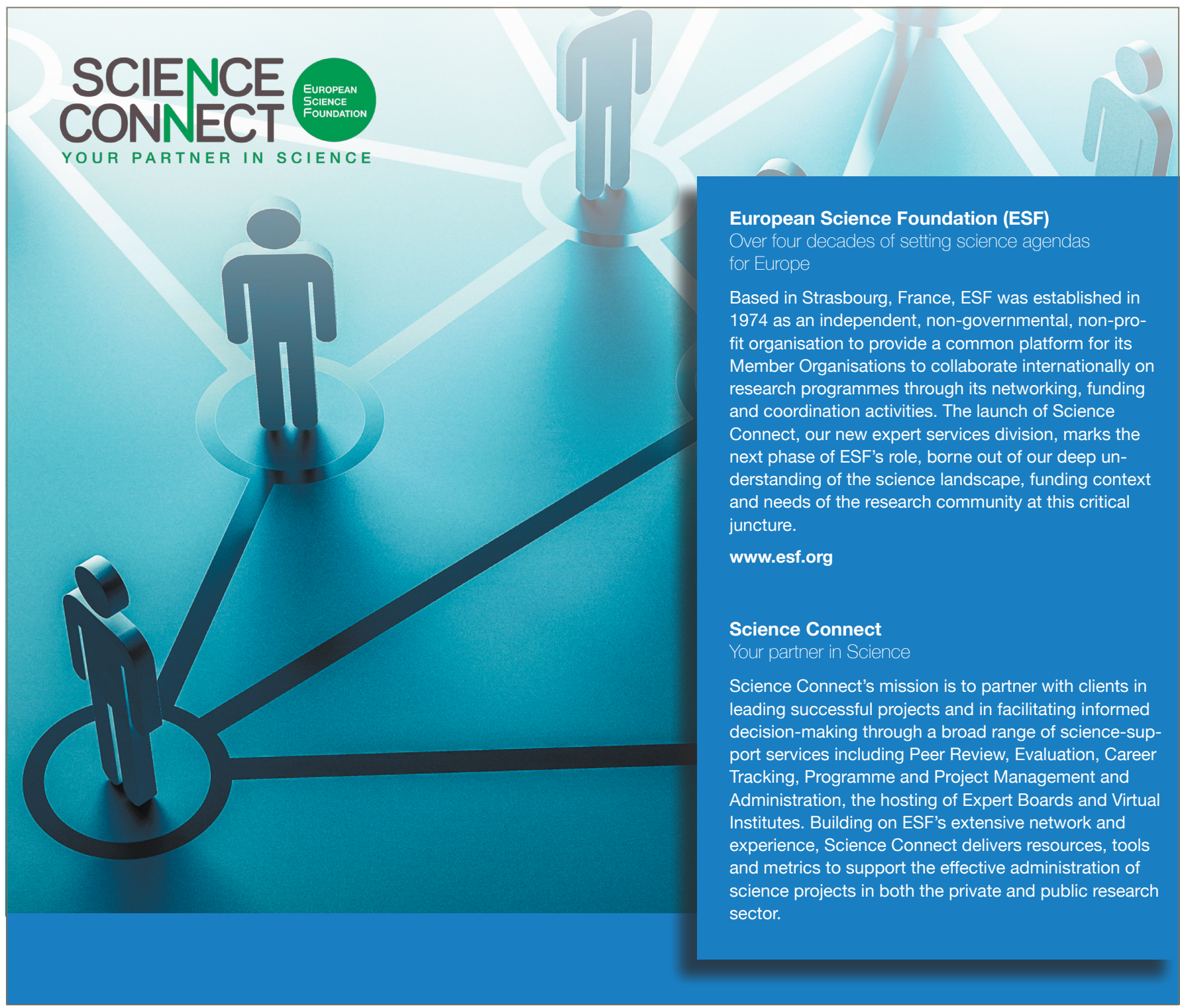

